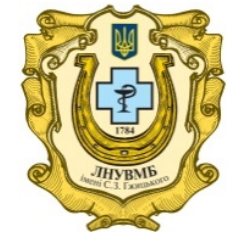

Ukrainian Journal of

Veterinary and Agricultural Sciences

http://ujvas.com.ua

Stepan Gzhytskyi National University of Veterinary Medicine and Biotechnologies Lviv

original article $\mid$ UDC 631.16(450) $\mid$ doi: 10.32718/ujvas2-1.03

Volume 2

Number 1

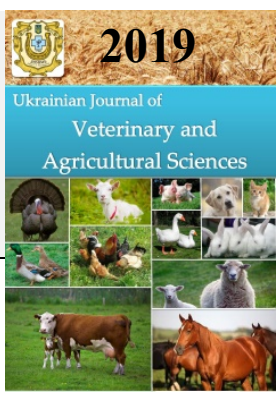

\title{
A long-term analysis of the common agricultural policy financial subsidies towards Italian farms
}

\author{
Nicola Galluzzo \\ Association of Geographical and Economic Studies of Rural Areas (ASGEAR) \\ Via Salaria per L'Aquila, 76 scala A \\ 02100 Rieti-Italy
}

\section{Article info \\ Received 04.02.2019 \\ Received in revised form 11.03.2019 \\ Accepted 12.03.2019 \\ Correspondence author \\ Galluzzo Nicola \\ E-mail: asgear@libero.it \\ (C) 2019 Galluzzo N. This is an open-access article distributed under the terms of the Creative Commons Attribution License, which permits unrestricted use, distribution, and reproduction in any medium, provided the original author and source are credited. \\ (cc) $\mathrm{BY}$}

\begin{abstract}
In Italy since 2000 there has been a significant decrease of farms and a notable increase of the usable agricultural areas. In order to reduce the socioeconomic marginalization in rural territories the European Union has supported financially the rural development in a pattern of pluriactivity and productive diversification in farms. The core purpose of this research was to assess by a multiple regression model the impact of financial subsidies allocated by the Common Agricultural Policy on the farmer net income since 2004 to 2016 in Italian farms belonging to the Farm Accountancy Data Network. Findings have pointed out a direct impact of financial supports disbursed by the European Union; by contrast, no impacts have had payments disbursed by the second pillar. Drawing the conclusions, it is fundamental to increase the financial supports of the Common Agricultural Policy aimed at implementing the land capital endowment which is the one of the main bottlenecks in Italian farms.
\end{abstract}

Key words: rural development, Farm Accountancy Data Network, less favoured areas, panel data, multiple regression model.

Contents

1. Introduction ................ 12

2. Materials and methods ....... 13

3. Results and discussion ...... 14

4. Conclusions ............... 16

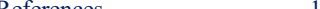

Citation:

Galluzzo, N. (2019). A long-term analysis of the common agricultural policy financial subsidies towards Italian farms. Ukrainian Journal of Veterinary and Agricultural Sciences, 2(1), 12-17.

\section{Introduction}

Comparing findings of the two Italian Agricultural censuses carried out in 2000 and in 2010 by the National Institute of Statistics (ISTAT) and also analysing the results assessed by secondary sources of data in Italy there has been a significant decrease of farms with negative consequences on the socioeconomic development in rural areas. Different authors have investigated in depth the evolution of farms and the reasons in supporting of a not univocal interpretation of this mismatch among statistical data assessed by the census and by other sources of data which is inherent to the economic unit of investigation (Sotte, 2005; Sotte \& Arzeni, 2006; Sotte, 2014). A partial positive aspect of this drop has been an increase of the usable agricultural area which in average equates to 8 hectares which, according to the recent data investigated by Eurostat, has been under the amount estimated in Europe close to 14.2 hectares (Galluzzo, 2014) hence, different should be the allocation of financial resources in order to promote an integrated economic growth in rural areas (Sotte, 2005; Sotte \& Arzeni, 2006; Sotte, 2014).

Roughly speaking the role of financial supports allocated in particular by the first pillar of the Common Agricultural Policy (CAP) decoupled by the level of production in farms and by the second pillar of the CAP, aimed at getting better the rural development in the countryside, have had an impact in some European agrarian enterprises and in their competitiveness (Zhu \& Lansink, 2010). These authors have also argued the notable effect of the Common Agricultural Policy financial subsidies to the efficiency of farms. Findings on the assessment of the new reform in the agrarian policy in the European Union during the seven-year time 2014-2020 have pointed out as it has been not easy for Italian farms to accept the recent changes and challenges of the new support initiatives financed by the Common Agricultur- 
al Policy which not always have had impacts in a significative way to the farmer's income (Frascarelli, 2014).

Some simulations on the effect of aids subsidizing the primary sector in Italy have underlined a dichotomy between rural and urban areas where are located the farms with a rising of supports allocated by the CAP per hectare of usable agricultural areas in extremely rural areas and a notable drop in urban territories (Sotte, 2014). However, the impact of financial subsidies is uneven in different European nations with direct effects towards the technical and economic efficiency of farms which has been influenced by the diffusion of decoupled payments (Latruffe et al., 2017); Rizov et al. in 2013 have argued as the transition from a coupled to a decoupled system of payments has had different effects in several European countries with positive impacts towards the productivity in lots of farms even if the degree of specialization and the dimension of farms in terms of usable agricultural areas have had notable implications on the efficiency (Zhu \& Lansink, 2010).

Severini and Tantari in 2013 have assessed by a quantitative approach as the direct payments allocated by the first pillar of the Common Agricultural Policy have had a negative impact on the level of farm net income. In order to assess the function of financial supports on the farmers the European Commission proposed and set up a sample analysis called Farm Accountancy Data Network (FADN). It was established in 1965 by the Council Regulation ECC 79 published in 1965. The FADN is a sample dataset made up of 11,000 Italian farms on a total amount of 80,000 holdings able to represent approximately 5 million of European enterprises throughout a common agricultural survey methodology in all member states of the European Union; the core target of this dataset is to investigate and to collect information about the impact of the Common Agricultural Policy in different countries in order to improve measures of financial support on farms financed by the Rural Development Programme and by other typology of decoupled payments (Galluzzo, 2014).

Aim of the research. The core purpose of this research was to assess by a quantitative approach such as the multiple regression model in all Italian farms belonging to the Farm Accountancy Data Network dataset the impact of financial subsidies allocated by the first and second pillar of the Common Agricultural Policy towards the farm's net income since 2004 to 2016.

\section{Materials and methods}

The Italian Farm Accountancy Data Network dataset has been made by all the farms investigated since 2004 to 2016 part of the sample hence, it is defined as a balanced panel data because of a complete dataset in the secondary source of investigated farms (Baltagi, 2011).

The observation units are represented by the Italian regions during a period of study 2004-2016 and they have generated a dataset of longitudinal panel data that can be modelled and assessed by using two different approaches such as fixed effects (FE) or random effects (RE). The choice between fixed effects and random effects model was decided by the application of a statistical test such as the Hausman test (Hausman, 1978). According to this latter author, the Hausman test measures the difference between the results of the two estimators fixed effects or alternately random effects. If there is a hypothesis of no correlation between the regressors identified in the model and the individual effects is accepted, the two assessments tend to be very similar to each other; if the estimates will tend to be significantly different, it is preferable to use the fixed effects model than the random effects one (Manera \& Galeotti, 2005; Galluzzo, 2014). The core advantage of the panel data is to assess the unobserved heterogeneity between units and the different aspects that characterize them.

In our investigation at the light of the results in the Hausman test considering also the need to compare different Italian regions, the hypothesis in using the random effect panel data in the multiple regression has been strengthened because it has been able to point out the differences among Italian regions.

Focusing in depth the panel data, it emerges as in the equation of random effect panel data there is a parameter $\mathrm{a}_{\mathrm{i}}$ made by independent and casual items distributed independently among the variables analysed in the model hence, the RE model can be written as (Greene, 2003; Verbeek, 2006):

$$
\begin{aligned}
Y_{\text {it }} & =\mu+X^{\prime}{ }_{i t} \beta+a_{i}+\varepsilon_{i t} \\
\varepsilon_{\text {it }} & \sim \operatorname{IID}\left(0, \sigma^{2}\right) \\
a_{i} & \sim \operatorname{IID}\left(0, \sigma^{2}{ }_{a}\right)
\end{aligned}
$$

and $\mathrm{a}_{\mathrm{i}}+\varepsilon_{\mathrm{it}}$ is the error made by a constant amount over the time which is correlated to each variable and by a residual component that is not correlated over the time hence, $\mathrm{a}_{\mathrm{i}}$ and $\varepsilon_{\mathrm{it}}$ are independent and not correlated to $\mathrm{X}_{\mathrm{js}}$ for every $\mathrm{j}$ and s (Verbeek, 2006).

At this stage of the research findings assessed in the random effect panel data have been compared to these outcomes estimated by the ordinary least square approach. The multiple regression model estimated by the panel data approach has been compared to the ordinary least square or rather to the pooled least square following the research approaches proposed by the Hausman test (Hausman, 1978). In this case the estimation of the main regressors in the equation of the multiple regression can be expressed in a form of matrix (Gujarati, 2004; Verbeek, 2006):

$$
\mathrm{y}=\mathbf{X} \beta+\varepsilon_{\mathrm{i}}
$$

with $\mathrm{i}=1, \ldots, \mathrm{n}, \mathrm{y}$ is the dependent variable and $\varepsilon$ is the statistical error (Verbeek, 2006; Asteriou \& Hall, 2011; Baltagi, 2011).

In this mathematical expression $\mathrm{y}$ and $\varepsilon_{\mathrm{i}}$ are vectors with n-dimensional, $\mathbf{X}$ is a matrix made by independent variables with a dimension $\mathrm{n} \mathrm{x} \mathrm{k}$ and $\beta$ is a set of estimated parameters able to explain their own impact towards the farmer's net income in Italian farms (Verbeek, 2006; Asteriou \& Hall, 2011; Baltagi, 2011; Galluzzo, 2017). The estimation of all parameters in the multiple regression model has been assessed by the software GRETL and using the software XLSTAT.

The basic assumptions of the multiple regression model are (Gujarati, 2004; Verbeek, 2006; Galluzzo, 2017; Galluzzo, 2018): the statistical error $\varepsilon_{\mathrm{i}}$ has a null conditional mean given $\mathrm{X}_{\mathrm{i}}$, that is $\mathrm{E}\left(\varepsilon_{\mathrm{i}} \mid \mathrm{X}_{\mathrm{i}}\right)=0$; $\left(\mathrm{X}_{\mathrm{i}}, \mathrm{Y}_{\mathrm{i}}\right), \mathrm{i}=1, \ldots ., \mathrm{n}$ are extracted independently and identically distributed (i.i.d.) from their joined distribution; $\mathrm{X}_{\mathrm{i}}$ and $\varepsilon_{\mathrm{i}}$ have finite fourth moments which are not zero; there is also no correlations between the regressors and the random noise hence, the value between $\beta$ expected and $\beta$ estimated is the same. 


\section{Results and discussion}

Research findings in the Farm Accountancy Data Network made by all Italian farms since 2004 to 2016 have pointed out as the average amount of land capital in terms of usable agricultural areas (UAA) is close to 18 hectares with notable fluctuations between 3 to 53 hectares (Table 1) which depend upon the specialization of farms in many times characterised by grassland and meadows that act in arising the usable agricultural surface. Focusing the attention on the economic parameters of the Italian farms it emerges as the average level of income in farms is close to 25,000 euro with a minimum of 7,000 euro and a maximum of more 100,000 euro; meagre is the provision of subsidies allocated by the second pillar of the Common Agricultural Policy in the Rural Development Programme (RDP payments) and the total amount of subsidies paid towards farms located in disadvantaged rural territories (LFA subsidies) hence, notable has been the value of total decoupled payments allocated by the first pillar of the Common Agricultural Policy. Whether in on one hand the level of assets in Italian farms, in terms of machinery and buildings, is higher in the other one modest is the amount of net investments in each agrarian enterprise; the incidence of the specific costs correlated to the agrarian productions such as fertilizers, pesticides and seeds on the total input are significant and it equates to $43 \%$.

Table 1

Descriptive statistics in all Italian farms part of FADN dataset over the years 2004-2016 (Source: author's elaboration on data http://ec.europa.eu/agriculture/rica/database/database_en.cfm)

\begin{tabular}{lccccc}
\hline \multicolumn{1}{c}{ Variables } & Unit & Min & Max & Mean & Std. deviation \\
\hline Usable Agricultural Areas (UAA) & ha & 3.19 & 52.93 & 18.22 & 9.99 \\
Total Inputs & $€$ & $11,191.00$ & $117,950.00$ & $37,593.14$ & $20,874.14$ \\
Total specific costs & $€$ & $3,164.00$ & $70,608.00$ & $16,088.07$ & $12,025.31$ \\
Total assets & $€$ & 123,337 & $1,117,783$ & 394,496 & 203,090 \\
Net Investments & $€$ & 10.000 & 108,881 & $5,088.26$ & $8,322.76$ \\
CAP total amount & $€$ & 525.00 & $22,546.00$ & $7,229.09$ & $4,338.49$ \\
LFA subsidies & $€$ & 0.00 & $7,276.00$ & 628.93 & $1,345.30$ \\
RDP payments & $€$ & 0.00 & $14,091.00$ & $1,577.55$ & $2,371.50$ \\
Farm net income & $€$ & $7,004.00$ & 116,073 & $25,963.2$ & $14,268.05$ \\
\hline
\end{tabular}

Table 2

Main correlations among all investigated variables year 2004. In bold are values of significance at 5\% (Source: author's elaboration on data http://ec.europa.eu/agriculture/rica/database/database_en.cfm)

\begin{tabular}{lccccccccc}
\hline \multicolumn{1}{c}{ Variable } & $\begin{array}{c}\text { Usable } \\
\text { Agricul- } \\
\text { tural Area }\end{array}$ & $\begin{array}{c}\text { Total } \\
\text { Inputs }\end{array}$ & $\begin{array}{c}\text { Total spe- } \\
\text { cific costs }\end{array}$ & $\begin{array}{c}\text { Total } \\
\text { assets }\end{array}$ & $\begin{array}{c}\text { Net In- } \\
\text { vestments }\end{array}$ & $\begin{array}{c}\text { CAP total } \\
\text { amount }\end{array}$ & $\begin{array}{c}\text { LFA } \\
\text { subsidies }\end{array}$ & $\begin{array}{c}\text { RDP } \\
\text { pay- } \\
\text { ments }\end{array}$ & $\begin{array}{c}\text { Farm net } \\
\text { income }\end{array}$ \\
\hline Usable Agricultur- & 1 & 0.342 & 0.367 & 0.352 & 0.003 & $\mathbf{0 . 7 1 5}$ & 0.369 & 0.360 & 0.297 \\
al Area & 0.342 & 1 & $\mathbf{0 . 9 6 8}$ & $\mathbf{0 . 8 6 0}$ & 0.321 & $\mathbf{0 . 4 5 5}$ & 0.034 & 0.126 & $\mathbf{0 . 8 4 6}$ \\
Total Inputs & 0.367 & $\mathbf{0 . 9 6 8}$ & 1 & $\mathbf{0 . 8 1 0}$ & 0.247 & $\mathbf{0 . 4 9 5}$ & 0.036 & 0.120 & $\mathbf{0 . 9 1 7}$ \\
Total specific costs & 0.352 & $\mathbf{0 . 8 6 0}$ & $\mathbf{0 . 8 1 0}$ & 1 & $\mathbf{0 . 5 9 5}$ & 0.417 & 0.102 & 0.184 & $\mathbf{0 . 7 4 5}$ \\
Total assets & 0.003 & 0.321 & 0.247 & $\mathbf{0 . 5 9 5}$ & 1 & -0.097 & -0.227 & -0.195 & 0.295 \\
Net Investments & $\mathbf{0 . 7 1 5}$ & $\mathbf{0 . 4 5 5}$ & $\mathbf{0 . 4 9 5}$ & 0.417 & -0.097 & 1 & $\mathbf{0 . 6 1 9}$ & $\mathbf{0 . 6 4 8}$ & 0.427 \\
CAP total amount & 0.369 & 0.034 & 0.036 & 0.102 & -0.227 & $\mathbf{0 . 6 1 9}$ & 1 & $\mathbf{0 . 9 8 5}$ & 0.027 \\
LFA subsidies & 0.360 & 0.126 & 0.120 & 0.184 & -0.195 & $\mathbf{0 . 6 4 8}$ & $\mathbf{0 . 9 8 5}$ & 1 & 0.117 \\
RDP payments & 0.297 & $\mathbf{0 . 8 4 6}$ & $\mathbf{0 . 9 1 7}$ & $\mathbf{0 . 7 4 5}$ & 0.295 & 0.427 & 0.027 & 0.117 \\
Farm net income & & & & & & & & & \\
\hline
\end{tabular}

The analysis of the main correlations at a level of significance of $5 \%$ among all investigated variable in two different years such as 2004 and 2016 has pointed out notable changes. During the year 2004 in all Italian farms part of FADN dataset it has emerged a direct correlation between the variable land capital endowment in terms of usable agricultural areas and the total amount of subsidies allocated by the first and second pillar of the Common Agricultural Policy (Table 2). The highest levels of correlations have been assessed between the variables total specific costs and total inputs and also between the variables payments disbursed by the second pillar of the CAP and total amount of subsidies allocated by the EU Common Agricultural Policy; by contrast, the lowest values of correlation have been pointed out among the variables CAP total amount and total inputs and total specific costs.

Drawing some preliminary conclusions, the higher is the level of farm net income the higher is the level of total specific costs and total assets hence, a noteworthy level of land capital endowment tightly linked to notable specific costs, or rather a higher level of crop specialization and total assets is able to act directly on the level of farm net income. 
Table 3

Main correlations among all investigated variables year 2016. In bold are value at a level of significance 5\% (Source: author's elaboration on data http://ec.europa.eu/agriculture/rica/database/database_en.cfm)

\begin{tabular}{lccccccccc}
\hline \multicolumn{1}{c}{ Variable } & $\begin{array}{c}\text { Usable Agri- } \\
\text { cultural Area }\end{array}$ & $\begin{array}{c}\text { Total } \\
\text { Inputs }\end{array}$ & $\begin{array}{c}\text { Total spe- } \\
\text { cific costs }\end{array}$ & $\begin{array}{c}\text { Total } \\
\text { assets }\end{array}$ & $\begin{array}{c}\text { Net In- } \\
\text { vestments }\end{array}$ & $\begin{array}{c}\text { CAP total } \\
\text { amount }\end{array}$ & $\begin{array}{c}\text { LFA } \\
\text { subsidies }\end{array}$ & $\begin{array}{c}\text { RDP } \\
\text { payments }\end{array}$ & $\begin{array}{c}\text { Farm net } \\
\text { income }\end{array}$ \\
\hline $\begin{array}{l}\text { Usable Agricul- } \\
\text { tural Area }\end{array}$ & 1 & 0.297 & 0.312 & 0.009 & 0.258 & $\mathbf{0 . 7 5 5}$ & $\mathbf{0 . 5 6 5}$ & $\mathbf{0 . 5 9 3}$ & 0.141 \\
$\begin{array}{l}\text { Total Inputs } \\
\text { Total specific }\end{array}$ & 0.297 & 1 & $\mathbf{0 . 9 8 1}$ & $\mathbf{0 . 8 3 2}$ & 0.353 & $\mathbf{0 . 4 8 3}$ & 0.026 & 0.052 & $\mathbf{0 . 9 1 8}$ \\
costs & 0.312 & $\mathbf{0 . 9 8 1}$ & 1 & $\mathbf{0 . 8 0 3}$ & 0.250 & $\mathbf{0 . 4 9 3}$ & 0.014 & 0.024 & $\mathbf{0 . 9 3 6}$ \\
Total assets & 0.009 & $\mathbf{0 . 8 3 2}$ & $\mathbf{0 . 8 0 3}$ & 1 & 0.260 & 0.201 & -0.094 & -0.083 & $\mathbf{0 . 8 1 8}$ \\
Net Investments & 0.258 & 0.353 & 0.250 & 0.260 & 1 & 0.251 & $\mathbf{0 . 5 0 1}$ & $\mathbf{0 . 4 4 7}$ & 0.179 \\
CAP total & $\mathbf{0 . 7 5 5}$ & $\mathbf{0 . 4 8 3}$ & $\mathbf{0 . 4 9 3}$ & 0.201 & 0.251 & 1 & $\mathbf{0 . 6 1 9}$ & $\mathbf{0 . 7 1 9}$ & 0.415 \\
amount & $\mathbf{0 . 5 6 5}$ & 0.026 & 0.014 & -0.09 & $\mathbf{0 . 5 0 1}$ & $\mathbf{0 . 6 1 9}$ & 1 & $\mathbf{0 . 9 6 9}$ & -0.018 \\
LFA subsidies & $\mathbf{0 . 5 9 3}$ & 0.052 & 0.024 & -0.08 & $\mathbf{0 . 4 4 7}$ & $\mathbf{0 . 7 1 9}$ & $\mathbf{0 . 9 6 9}$ & 1 \\
RDP payments & 0.141 & $\mathbf{0 . 9 1 8}$ & $\mathbf{0 . 9 3 6}$ & $\mathbf{0 . 8 1 8}$ & 0.179 & 0.415 & -0.018 & 0.000 \\
Farm net income & & & & & & & 0.000 & 1 \\
\hline
\end{tabular}

Table 3 shows the main correlations assessed in 2016 in all Italian farms part of Farm Accountancy Data Network dataset. The highest values of correlations at a level of significance of $5 \%$ have been found between the variables total inputs and total specific costs, between the variables financial subsidies allocated by the National Rural Development Programme and LFA payments in favour of disadvantaged rural areas. In 2016 as previously assessed in 2004 the variable farm net income correlates directly to the variable total specific costs, total assets and total input in farms. The lowest correlation has been pointed out between the variables net investments and rural development programme subsidies. Summing up, the lower is the level of inputs in farm the lower is the total amount of subsidies allocated by the first and second pillar of the Common Agricultural Policy. In general, the majority level of financial subsidies allocated in the second pillar of the CAP is directly correlated to the payments in favour of disadvantaged rural areas and in these stayed behind territories it is important to raise the level of aids and financial supports disbursed by the second pillar of the Common Agricultural Policy with the purpose to im- plement the investments and the assets in farms which are sensitive to farm net income.

A first model of multiple regression estimated by the ordinary least square with the standardisation of a small group of variables has underlined as the dependent variable farm net income correlates directly to the variables total specific costs, total assets, total financial subsidies allocated by the Common Agricultural Policy both in the first pillar and also in the second one and to the payments disbursed in favour of farms located in disadvantaged rural areas (Table 4).

An indirect correlation has been found among the dependent variable farm net income and the independent variables land capital endowment and total input. In the light of these findings a notable level of farmer's net income has been estimated in farms located in disadvantaged rural areas receiving noteworthy financial subsidies allocated by the CAP, with a modest level of assets and characterized by a meaningful level of specific costs but in the same time lower have been the land capital endowment and the input used in the process of production.

Table 4

Main findings in the multiple regression model with the normalization of all variables. Dependent variable farm net income. (Source: author's elaboration on data http://ec.europa.eu/agriculture/rica/database/database_en.cfm)

\begin{tabular}{lcccccc}
\hline \multicolumn{1}{c}{ Variable } & Parameter & $\begin{array}{c}\text { St. } \\
\text { error }\end{array}$ & $\begin{array}{c}\text { T } \\
\text { value }\end{array}$ & $\operatorname{Pr}>|\mathrm{t}|$ & $\begin{array}{c}\text { Lower } \\
(95 \%)\end{array}$ & Upper (95\%) \\
\hline Usable Agricultural areas & -0.242 & 0.050 & -4.845 & $<0.0001$ & -0.340 & -0.144 \\
Total Inputs & -0.460 & 0.150 & -3.062 & 0.002 & -0.756 & -0.164 \\
Total specific costs & 1.030 & 0.141 & 7.310 & $<0.0001$ & 0.752 & 1.307 \\
Total assets & 0.158 & 0.062 & 2.529 & 0.012 & 0.035 & 0.281 \\
Net Investments & -0.010 & 0.033 & -0.294 & 0.769 & -0.076 & 0.056 \\
CAP total payments & 0.368 & 0.072 & 5.107 & $<0.0001$ & 0.226 & 0.510 \\
LFA payments & 0.296 & 0.150 & 1.976 & 0.049 & 0.001 & 0.591 \\
RDP subsidies & -0.301 & 0.169 & -1.782 & 0.076 & -0.634 & 0.032 \\
\hline
\end{tabular}

Research findings in the multiple regression model on the panel data assessed using a random effect over the time 2004-2016 have pointed out a none effect of financial supports allocated by the second pillar of the Common Agricul- tural Policy and by contrast a direct impact of the total amount of aids disbursed by the CAP in the first and second pillars (Table 5). 
Table 5

Main findings in the multiple regression model estimated by random effect panel data. Dependent variable farm net income. (Source: author's elaboration on data http://ec.europa.eu/agriculture/rica/database/database_en.cfm)

\begin{tabular}{|c|c|c|c|c|c|}
\hline Variable & Coefficient & Std. Error & $\mathrm{Z}$ value & p-value & Significance \\
\hline Constant & $11,584.6$ & 1554.53 & 7.4522 & $<0.0001$ & $* * *$ \\
\hline $\begin{array}{l}\text { Usable Agricultural Areas } \\
\text { (UAA) }\end{array}$ & 306.527 & 68.0296 & 4.5058 & $<0.0001$ & $* * *$ \\
\hline Total specific costs & 1.05025 & 0.087294 & 12.0311 & $<0.0001$ & $* * *$ \\
\hline Total farming overheads & 1.09087 & 0.22709 & 4.8036 & $<0.0001$ & $* * *$ \\
\hline Total assets & 0.01194 & 0.004084 & 2.9235 & 0.0035 & $* * *$ \\
\hline CAP subsidies & 1.08395 & 0.214806 & 5.0462 & $<0.0001$ & $* * *$ \\
\hline RDP payments & 0.337162 & 0.292309 & 1.1534 & 0.2487 & n.s. \\
\hline
\end{tabular}

n.s. stands for not significance; $* * * \mathrm{p}$ value $<0.001$

Drawing some preliminary conclusions, the model of regression has strengthened the role of the Common Agricultural Policy as a whole in Italian farms. In general, the higher is the land capital endowment in Italian farms the higher is the amount of farmer's net income. Furthermore, increasing the level of investments, in terms of total assets in farms, there has been a significant growth of specific costs tightly linked to the production process and with the machinery and building endowment with a direct increase of farm net income.

The multiple regression model estimated using the ordinary least square has pointed out different correlations compared these results to the outcomes assessed with the random effect panel data (Table 6). In fact, with the exception of the financial subsidies allocated by the second pillar of the Common Agricultural Policy which did not affect the level of farmer's net income, the variables usable agricultural areas, total farming overheads have been correlated indirectly to the level of income in Italian farms. Focusing in depth the research outcomes, the dependent variable farm net income has been directly correlated to the variable total specific costs, total assets and amount disbursed by the CAP in those two pillars. The values of $\mathrm{R}^{2}$ and adjusted $\mathrm{R}^{2}$ have been equal to 0.73 and 0.72 hence, an increasing in the number of variables investigated in the model has not had a significant incidence on the total variance and furthermore the model of regression by the ordinary least square has been able to explain more than $70 \%$ of the variance.

\section{Table 6}

Main findings in the multiple regression model estimated by the ordinary least square. Dependent variable farm net income (Source: author's elaboration on data http://ec.europa.eu/agriculture/rica/database/database_en.cfm)

\begin{tabular}{|c|c|c|c|c|c|}
\hline Variable & Coefficient & Std. Error & $Z$ value & p-value & Significance \\
\hline Constant & 10,981 & $1,191.34$ & 9.2174 & $<0.0001$ & $* * *$ \\
\hline Usable Agricultural Areas & -317.469 & 89.7022 & -3.5391 & 0.0041 & $* * *$ \\
\hline Total specific costs & 0.994719 & 0.157655 & 6.3095 & $<0.0001$ & $* * *$ \\
\hline Total farming overheads & -0.986842 & 0.33247 & -2.9682 & 0.0117 & $* *$ \\
\hline Total assets & 0.013052 & 0.004698 & 2.7782 & 0.0167 & $* *$ \\
\hline CAP subsidies & 1.13725 & 0.324204 & 3.5078 & 0.0043 & $* * *$ \\
\hline RDP payments & -0.324749 & 0.355763 & -0.9128 & 0.3793 & n.s. \\
\hline
\end{tabular}

n.s. stands for not significance; ${ }^{* *} \mathrm{p}$ value $0.01 ;{ }^{* * *} \mathrm{p}$ value $<0.001$

\section{Conclusions}

Since the Mac Sharry reform has been established in the early 1990s, the European Union has sought to subsidise in a decoupled way farmer and in this pattern both the first and second pillar of the Common Agricultural Policy have been pivotal in couching the out rural emigration and the socioeconomic marginalization in rural territories. Findings have pointed out lots of bottlenecks linked to the modest dimension of farms in order to getting better the farm net income which notably fluctuates among all Italian regions. In the last years of observation 2016 the role of financial subsidies allocated towards rural areas has been more intense than in the previous investigated year 2004.

Summing up, for the future it is important to stimulate public administrations at a local level which jointly with the funds allocated by the European Union should intensify the farms' merging phase in upland areas with the purpose the increase the land capital endowment in areas where ageing is a disastrous issue. Some proposals for the next seven-year time of rural development planning have to reallocate and beef up subsidies to the second pillar towards disadvantaged rural areas draining resources from the first pillar. Furthermore, an unique national programme could be a fruitful opportunity in order to modulate different financial resources within Italian regions considering as in Italy but it extensively is the same in all European Union countries there are different agricultures and models of agrarian production that need specific cohesive measures of socioeconomic growth with a bottom-up approach instead of a pattern of intervention planning in a framework based on general peculiarities and specificities of the countryside and its socioeconomic fabric. 


\section{References}

Asteriou, D., \& Hall, S.G. (2011). Applied econometrics second edition. Palgrave Macmillan, New York.

Baltagi, B.H. (2011). Econometrics. Springer-Verlag, Berlin Heidelberg. doi: 10.1007/978-3-642-20059-5.

Frascarelli, A. (2014). Gli impatti aziendali della riforma della Pac 2014-2020. [The impact for farms of CAP reform 2014-2020]. Agriregionieuropa, 38, 1-4. https://agriregionieuropa.univpm.it/ it/content/article/31/38/gli-impatti-aziendali-della-riforma-dellapac-2014-2020 (in Italian).

Galluzzo, N. (2018). A quantitative analysis of the CAP towards rural Romanian areas. In: $162^{\text {nd }}$ Seminar European Association of Agricultural Economists (EAAE), April 26-27 2018, Budapest, Hungary. http://ageconsearch.umn.edu/record/271963/ files/Galluzzo.pdf.

Galluzzo, N. (2017). The impact of the Common Agricultural Policy on the agritourism growth in Italy. Bulgarian Journal of Agricultural Science, 23(5), 698-703. https://journal.agrojournal.org/page/en/details.php?article_id=8 $28 \& \mathrm{tab}=\mathrm{en}$.

Galluzzo, N. (2014). The evolution of Italian farms and the role of subsidies paid by the European Union for rural development. Romanian Review of Regional Studies, 10(1), 79-88. https://search.proquest.com/openview/f8ded8bfca4b1c9d898fe $7 b 506192 \mathrm{f} 67 / 1$ ?pq-origsite $=$ gscholar\&cbl $=2030003$.

Greene, W.H. (2003). Econometric analysis. Delhi, Pearson Education.

Gujarati, D.N. (2004). Basic econometrics fourth edition. The McGraw-Hill Companies, New York.

Hausman, J.A. (1978). Specification tests in econometrics. Econometrica: Journal of the econometric society, 46(6), 1251-1271. doi: 10.2307/1913827.

Latruffe, L., Bravo-Ureta, B.E., Carpentier, A., Desjeux, Y. \& Moreira, V.H. (2017). Subsidies and technical efficiency in ag- riculture: Evidence from European dairy farms. American Journal of Agricultural Economics, 99(3), 783-799. doi: 10.1093/ajae/ aaw077.

Manera, M., \& Galeotti, M. (2005). Microeconometria. Metodi e applicazioni. [Microeconometrics. Methods and applications]. Roma, Carocci (in Italian).

Rizov, M., Pokrivcak, J., \& Ciaian, P. (2013). CAP subsidies and productivity of the EU farms. Journal of Agricultural Economics, 64(3), 537-557. doi: 10.1111/1477-9552.12030.

Severini, S., \& Tantari, A. (2013). The impact of agricultural policy on farm income concentration: the case of regional implementation of the CAP direct payments in Italy. Agricultural Economics, 44(3), 275-286. doi: 10.1111/agec.12010.

Sotte, F. (2005). Affinché riprenda la riflessione strategica sul futuro della PAC. [In order to resume a strategic analysis on the future of the CAP]. (in Italian). Available on the website: http://utenti.dea.univpm.it/sotte/ultime $\% 20$ pubblicazioni $\% 20 \mathrm{p}$ df/SWOT\%20x\%20GDB\%20it\%2031gen05.pdf.

Sotte, F. (2014). La geografia della nuova PAC in Italia. [The geography of the new CAP in Italy]. Agriregionieuropa, 38, 11-15. https://agriregionieuropa.univpm.it/it/content/article/ 31/38/la-geografia-della-nuova-pac-italia (in Italian).

Sotte, F., \& Arzeni, A. (2006). Imprese e non-imprese nell'agricoltura italiana. [Entreprises and not entreprises in Italian agriculture]. Politica agricola internazionale, 1, 13-30. http://utenti.dises.univpm.it/sotte/ultime\%20pubblicazioni $\% 20$ pdf/Imprese\%20non-imprese\%20ita\%20no1-2006\%2013$30 \% 20$ versione $\% 20$ pubblicata.pdf (in Italian).

Verbeek, M. (2006). Econometria. [Econometrics]. Zanichelli, Bologna (in Italian).

Zhu, X., \& Lansink, A.O. (2010). Impact of CAP subsidies on technical efficiency of crop farms in Germany, the Netherlands and Sweden. Journal of Agricultural Economics, 61(3), 545564. doi: 10.1111/j.1477-9552.2010.00254.x. 